\title{
DOMINANT LANGUAGE LEARNING STRATEGIES USED BY MANAJEMEN DAKWAH DEPARTMENT STUDENTS AT UIN MATARAM
}

\author{
Afif Ikhwanul Muslimin \\ UIN Mataram, afifikhwanulm@uinmataram.ac.id
}

\begin{abstract}
One of the prominent skills to be acquired by English language learners is Language Learning Strategies (LLSs), which is significant to enhance communicative competence. Although individual's differences in using the strategies depict their understanding on LLSs, very little research has been done in accordance with learners' language learning strategies especially in NonEnglish Department classroom. For this reason, this descriptive qualitative case study aimed to document the dominant LLSs used by ten successful students or achievers in English class who have the criteria of achieving English score above 90. The present study was carried out in English reading classroom at the Department of Management Dakwah (Islamic Preaching) of UIN Mataram (State Islamic University). Grounded in the data garnered from documentation, questionnaire, and interview, it was unveiled that that the students used all LLSs and created their own learning opportunities. Only $\mathrm{HN}$ did not use social strategy though he used all other strategies. Accordingly, all LLSs are significant for building up their language learning. In addition, the dominant types of LLSs used are compensation, memory and metacognitive strategy. Those strategies are good for inferencing the unfamiliar words, memorizing and retaining the vocabulary in mind, and creating best setting for them to learn, respectively. To this end, all English teachers need to be aware of students' language learning strategies in order to be more effective. To support the significance of LLSs in EFL context, further study might be conducted to investigate teachers' and students' perception and attitude towards LLSs.
\end{abstract}

Keywords: Language Learning Strategies, MDDSs, Dominant LLSs, English Scores.

\section{INTRODUCTION}

In tertiary level of education, Non-English department students study English diversely from English department ones. 
The English department students study general English, while the other group equips themselves with English for specific purpose (ESP). As a must course, ESP is set to be taught in the beginning of the study year to make the students equipped with a learning skill that is considered important to support their subject understanding in the next years (Sulistyo, 2008).

Day and Krzanowski (2011) define ESP as understanding and mastering special skills or language that is required by specific learners for special purpose. Here, learners do not learn English in general, but they focus more on ideas as being reflected in their field of study. The main concern in ESP courses is not a cut and parcel of the communicative repertoire of expert native as can be found in general English class (Ahmed, 2014). For this reason, ESP does not teach merely what English is, but it is about how to use English in learners' specific field including Reading skills on Manajemen Dakwah Department English subject materials.

An interesting fact on the result of Manajemen Dakwah Department Students (MDDSs) in UIN Mataram (odd semester, academic year 2018-2019) was 64 students getting higher English average scores(88) for their final test than in their pretest (65). Furthermore, there were 10 MDDSs who had been chosen as the subject as they achieved scores above 90 . As a result, they had successfully learnt English in Non-English Department class since the minimum requirement to achieve $\mathrm{A}+$ is 90 . That the score is 88 for the class average shows high improvement ranged from 65 . Hence, the MDDSs might use certain language learning strategies (LLSs) to gain higher English subject scores. A number of researches have shown students with various language abilities use different ways and using quantities of language learning strategies in foreign language learning (Peacock \& Ho, 2003).

Language learning strategies is one aspect that needed to be paid attention since the strategies are significance to increase communicative competence which is required in English skills (Oxford, 1990). Creating the understanding of language learning strategies is one of tool to hold conscious learning as way to obtain better proficiency especially in acquiring language competence. The 
LLSs is a very beneficial equipment to hold active and conscious learning, since the strategies provide better proficiency, autonomy in learning, and self-regulation (Dornyei \& Ryan, 2015).

Oxford (1990) stated that the language learning strategies are classified into six, namely memory strategy, metacognitive, cognitive strategy, compensation strategy, affective strategy, and social strategies. Different learners in term of gender, language level proficiency, belief, etc. had shown different language learning strategies (Dornyei \& Ryan, 2015). Furthermore, the learners individually choose, combine, and sequence language learning strategies in different ways.

Different learners in terms of high, middle, or low achievement also reflects their understanding in using the language learning strategies. However, it is believed that there is the most powerful strategies in learning the language as Saville-Troike (2006) stated that not all strategies are balance or in similar level. There is strategy which is more effective than other. Consequently, it is important to know which strategies are used by successful learners or the high achievers, as in their language performance showing good achievement that reflecting effectively using the LLSs. In relation with the using of strategies, the former researches had mentioned that good language learners are students that use consistently certain strategy like guessing the meaning from the clues i.e. context (Oxford, 2003).

However, very little research has been done in accordance with learners' language learning strategies especially in Non-English Department classroom. Hsiao and Oxford (Maftoon et al., 2011), moreover, found that good language learners mostly pay attention in fluency rather than accuracy and searching for communicative opportunities because they understand that language is a tool to communicate. Another research, Cabaysa and Baetiong (2010) stated that affective strategy, metacognitive, social strategy, and compensation strategy are most used by the learners. Different idea mentioned by Rachmawati (2013) that tells the most frequent language learning strategy used by SMA Cimahi students are compensation strategy and the least used are memory and affective 
strategies. In the same year, Tam (2013) did research on Language learning strategies used by students in Hong Kong University. He found that male students and female students used only five strategies, involving memory, metacognitive, compensation, social, and cognitive strategies.

Furthermore, looking at the limited amount of the researches exploring language learning strategies conducted so far also considering the importance of LLSs in improving the learners' autonomy in EFL learning, the researcher has tried to check the types of language learning strategies and the dominant one that were used by Manajemen Dakwah Department Students at UIN Mataram and the frequency of its application based on their learning achievement.

\section{REVIEW OF LITERATURE}

The word "Strategy" is derived from the ancient Greek namely strategia. It refers to the generalship or the art of battle. Specifically, this word relates to the optimal and effective management of soldiers, war vessels or fighter jets in a planned campaign. "Tactics" is closely related to strategies which mean tools to achieve the winning in using strategies. Moreover, the two expressions share some basic concepts: planning, conscious manipulation, competition, and movement toward objectives. In non-military settings, the concept of strategy has been employed to the non-adversarial conditions and situations, where it means planning, steps or actions that are taken for achieving specific goals (Oxford, 1990). Strategies are particularly significant for language learning because they are tools for self-directed involvement, active, which are essential for improving communicative competence. Because of its significance, learning strategies have been extensively used in the educational area.

As the effort to define language learning strategy, some researchers used different terms and concepts (Oxford \& Crookall, 1989). Oxford and Crookall (1989) defined LLSs as steps which are taken by the learners to boost their storage, acquisition, and retrieval of information. They recognize that strategies may be used 
consciously but they can also become habitual and automatic with practice. The same idea, Oxford (1990) stated that LLSs are steps taken by students to enhance their learning. He explained the learning strategies is as specific actions done by the learner to establish easier, more self-directed, faster, more enjoyable, more effective, and more transferable learning situations.

Oxford (1990) the language learning strategies are divided into six, namely: memory strategy, metacognitive, cognitive strategy, compensation strategy, affective strategy, and social strategies. Different learners in term of gender, language level proficiency, belief, etc had shown different language learning strategy (Dornyei \& Ryan, 2015). Furthermore, the learners individually choose, combine, and sequence language learning strategies in different ways.

\section{RESEARCH METHOD}

The research is a descriptive qualitative case study involving 10 students of Manajemen Dakwah Department (bachelor program) of UIN Mataram who had been chosen since they achieved English subject score above 90 while the average score for the whole class final test was 88 which meant showing high improvement from average score 65 for the pretest. They studied English focusing for Reading skills in odd semester academic year 2018-2019 and passed English I program. They also picture the successful English language learners through English performances. As a descriptive study, it focuses on specific nature of individual subject and go deeply and in detail way to describe the subject. The aforementioned approach is called case study as it tries to describe the subjects' entire range of behavior and the relationship of the behaviors to the environment (Ary, Jacobs, \& Razavieh, 2002: 440).

The research directly helps to know the language learning strategies used by successful Non-English Department Students at UIN Mataram. This is prominent technique while the objectives of the study is to draw the data obtained from the sample selected, 
like this study's objective: to depict how often the language learning strategies used by successful Non-English Department Students, MDDSs of UIN Mataram regarding their learning achievement in English subject.

In the present study, three instruments were used to gather data, they are: documentation, questionnaire, and interview. Documentation was done in order to get the MDDSs English subject scores data to short from the highest to the lowest. The second instrument was questionnaire. Creswell (2012) asserted that questionnaire start with demographic or personal question that respondents can easily answer, and are committed to complete the form. Language learning strategies questionnaire was taken from Strategy Inventory for Language Learning (SILL) by Oxford (1990) was modified by researcher in order to match with the objective of this study. In the SILL language learning strategies are categorized as: (a) memory strategy (9 items) that depict remembering effectively, (b) cognitive strategy (14 items) that describe using mental process, (c) compensation strategy (6 items) that show compensating for missing knowledge, (d) metacognitive strategy ( 9 items) that explain organizing and evaluating the learning, (e) affective strategy (6 items) that pictures managing emotion, and ( $\mathrm{f}$ ) social strategy (6 items) that represents studying with others.

Table 1 the SILL Questionnaire

\begin{tabular}{lcl}
\hline \multicolumn{1}{c}{ Division } & $\begin{array}{c}\text { Number } \\
\text { of items }\end{array}$ & \multicolumn{1}{c}{ Items } \\
\hline Memory strategy & 9 & $1,2,3,4,5,6,7,8,9$ \\
Cognitive strategy & 14 & $10,11,12,13,14,15,16,17,18$, \\
& & $19,20,21,22,23$ \\
Compensation strategy & 6 & $24,25,26,27,28,29$ \\
Metacognitive strategy & 9 & $30,31,32,33,34,35,36,37,38$ \\
Affective strategy & 6 & $39,40,41,42,43,44$ \\
Social strategy & 6 & $45,46,47,48,49,50$ \\
\hline
\end{tabular}


The above questionnaire used five points Likert scales with the description of: 1: never, 2: rarely, 3: sometimes, 4: often, 5: always. Learners were commanded to respond to each item honestly.

Then, SILL was accompanied by interview questions (see Appendix 1) which the respondent should give their judgment. These questions were for digging out the learner profiles and information related to the language learning strategies they used. The questionnaires asked in this study had seven topics. The topics used to elicit the respondents' needs were: (1) the interest of learning English, (2) the strategies of learning English, (3) the frequency of using English, (4) the opinion on improving English competence in English, (5) the confidence of the English competence, (6) the achievements in English competition or event

For collecting the data, there were some activities with the description tabulated in following table:

Table 2 The Schedule of the Documentation and Questionnaire Administration

\begin{tabular}{|c|c|c|c|c|}
\hline Date & Activity & Place & Instrument & $\begin{array}{c}\text { Numbers } \\
\text { of } \\
\text { Learners }\end{array}$ \\
\hline $\begin{array}{c}\text { September } \\
2018\end{array}$ & $\begin{array}{l}\text { Pre-testing } \\
\text { MDDSs to } \\
\text { acquire their } \\
\text { reading ability } \\
\text { average score }\end{array}$ & $\begin{array}{c}\text { Room } \\
\text { 6a, } \\
\text { MDD, } \\
\text { FDIK, } \\
\text { UIN } \\
\text { Mataram }\end{array}$ & $\begin{array}{c}\text { Documentation } \\
\text { of students } \\
\text { scores report }\end{array}$ & 64 \\
\hline $\begin{array}{c}\text { December } \\
2018\end{array}$ & $\begin{array}{l}\text { Questionnaire } \\
\text { administration } \\
\text { for } 10 \\
\text { MDDSs high } \\
\text { final test } \\
\text { scores } \\
\text { achievers }\end{array}$ & $\begin{array}{c}\text { Room } \\
\text { 6a, } \\
\text { MDD, } \\
\text { FDIK, } \\
\text { UIN } \\
\text { Mataram }\end{array}$ & $\begin{array}{c}\text { SILL } \\
\text { questionnaire }\end{array}$ & 10 \\
\hline December & Interview & MD & Interview list & 10 \\
\hline
\end{tabular}




\section{FINDING AND DISCUSSION}

\subsection{MDDSs' Language Learning Strategies}

Language learners can learn effective strategies in learning a foreign language. Those who apply and use some learning strategies are more likely to continue their language learning after the class has been completed and thus maintaining their foreign language skills than learners who have no grounding in strategies (Oxford, 2003). It is true when students learn a language they cannot get their success since they do not know what and how to get the language. Training in learning strategies help learners become aware of strategies they use and wide variety of available strategies (Oxford, 2003). In Indonesia, some studies of learning strategies were done to show the important role of learning strategies in determining the students' success in learning a target language. In her research, Susilowati (2010) proved that training in a learning strategy gave a significant impact on students writing skill. The same statement, Mistar (2001) explains that motivational factors influence learners to use the language learning strategies significantly compared to personality character or language aptitude. In further research, he mentioned that language learning strategies influence the proficiency attainment.

The objective of the language learning strategies is to develop communicative competence (Oxford, 1990). Hence, the classification is two: they are direct and indirect that further being divided into six groups. In the system created by Oxford, metacognitive strategy leads students to control their own learning. Affective strategy is related to learners' emotional situation such as being confidence. Then, social strategy leads to improvement of interaction with language they learn. Cognitive strategy are the mental strategy learners use to make sense of the learning, ability to store the information is using memory strategy, and the ability to remove gaps in continuing the communication is compensation 
Muslimin, A. I., Dominant Language ...

strategy. Taxonomy of language learning strategies by Oxford (1990) is described in Table 3.

Table 3 Oxford Taxonomy of Language Learning Strategies.

\begin{tabular}{rrr}
\hline \multicolumn{1}{c}{ Direct } & Indirect \\
\hline I $\quad$ Memory & I & Metacognitive \\
& a. Creating mental & a. Focusing \\
& linkage & learning \\
b. Applying images & b. Arranging \\
& and sounds & learning \\
c. Reviewing well & c. Evaluating \\
d. Employing action & & learning \\
\hline
\end{tabular}

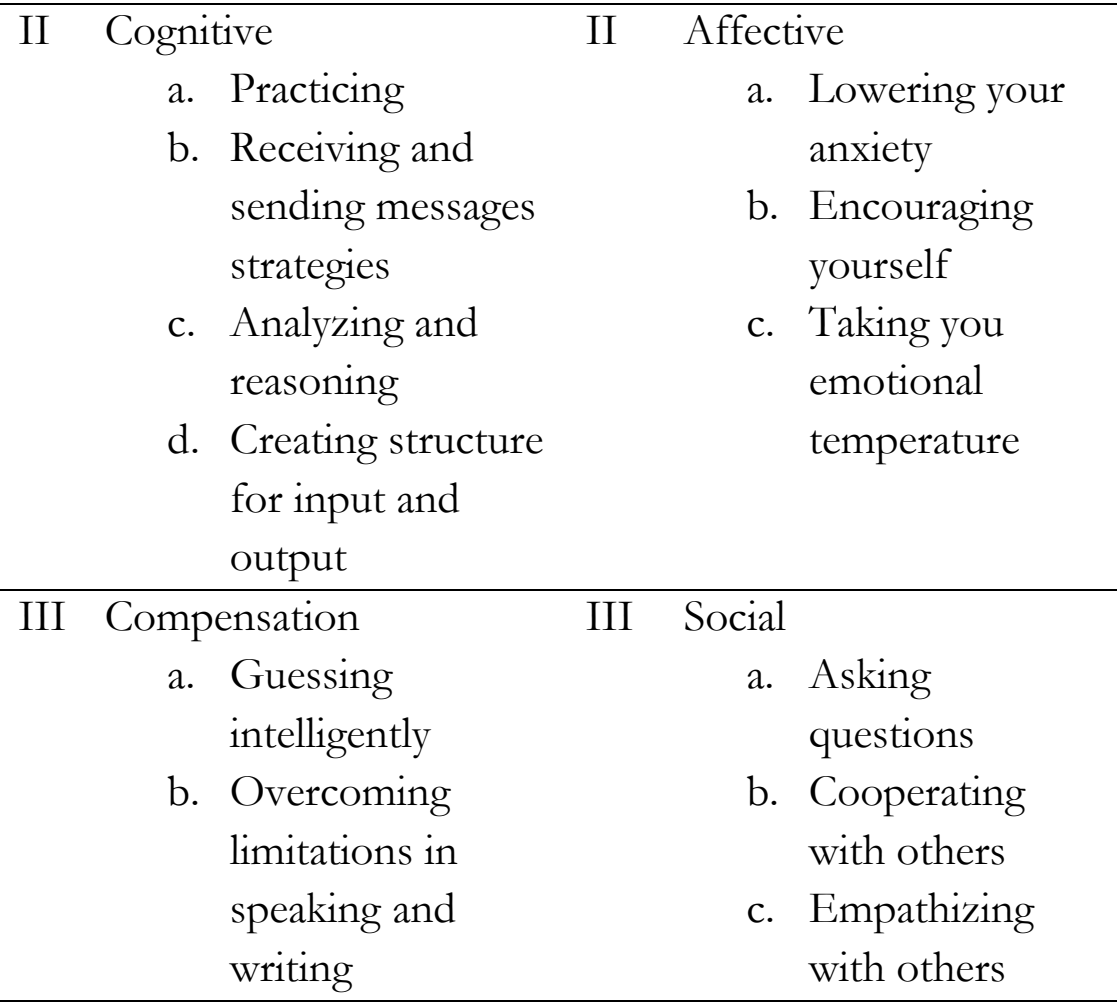

This is clear that many of the latest works in this field have been characterized by a large concept of language learning 
strategies which go beyond cognitive processes to involve social and communicative strategies. The research explains that the MDDSs used learning strategies as described in following Table :

Table 4 Language Learning Strategies Used by Each Learner

\begin{tabular}{cccccccccccc}
\hline \multirow{2}{*}{ Respondent } & & $\mathrm{H}$ & $\mathrm{A}$ & $\mathrm{N}$ & $\mathrm{SD}$ & $\mathrm{SP}$ & $\mathrm{MJ}$ & $\mathrm{LF}$ & $\mathrm{DR}$ & $\mathrm{M}$ & \multirow{2}{*}{$\mathrm{N}$} \\
\cline { 2 - 10 } & 1 & 2 & 3 & 4 & 5 & 6 & 7 & 8 & 9 & 10 & $\mathrm{x}$ \\
\hline Memory & 25 & 39 & 33 & 30 & 31 & 42 & 35 & 34 & 36 & 24 & 45 \\
\hline Cognitive & 58 & 55 & 55 & 54 & 53 & 48 & 57 & 57 & 43 & 45 & 70 \\
\hline $\begin{array}{c}\text { Compensati } \\
\text { on }\end{array}$ & 25 & 16 & 25 & 23 & 25 & 25 & 22 & 25 & 17 & 20 & 30 \\
\hline $\begin{array}{c}\text { Metacogniti } \\
\text { ve }\end{array}$ & 38 & 44 & 37 & 32 & 28 & 34 & 37 & 36 & 33 & 31 & 45 \\
\hline Affective & 23 & 19 & 22 & 20 & 19 & 17 & 20 & 18 & 17 & 25 & 30 \\
\hline Social & 26 & 15 & 23 & 19 & 18 & 17 & 22 & 17 & 17 & 18 & 30 \\
\hline Total & 19 & 18 & 19 & 17 & 174 & 18 & 193 & 187 & 163 & 16 & \\
\hline
\end{tabular}

Table 5. Language Learning Strategies Used by Each Learners in Percent

Types of Learning Strategies Frequency

Percentage

$(\%)$

A. Direct
1. Memory
10
16.9
2. Cognitive
10
16.9
3. Compensation
10
16.9

B. Indirect

1. Metacognitive 10

2. Affective

3. Social

9

15.2

Total

59

100


From table 4 and table 5, it can be inferred that the learners used both direct and indirect learning strategies. It means that they needed all strategies to uphold their learning experience. The direct strategies had been utilized by all of the learners, while there was only one learner who did not use the indirect strategies of social strategy. The direct strategies directly help learners to acquire the foreign language. In memory strategy, they did some actions like creating mental image by grouping and associating, placing words into a context, using keywords to indicate something, using sound, doing semantic mapping, and employing action by doing physical responses. Then, in cognitive strategies the learners mentioned several things they always did, such as analyzing expressions and contrastive concept across languages, translating, taking notes, summarizing, repeating, practicing naturally, getting an idea quickly, and practicing formally with sounds and writing system. Next, the learners mentioned some activities such as guessing, using synonyms, and getting helps in compensation strategies.

Seen from the indirect strategies, metacognitive strategies like seeking practice opportunities, deciding aims, and focusing on listening were done. Then, lowering anxiety and taking the learners' emotional temperature were done in affective strategies. Lastly, to convey the social strategies, the learners mentioned that they always cooperated with proficient users of the language and asked for clarification and verification.

As mentioned above, the learners have disclosed their stories of learning English and their activities to improve and maintain their English. Learning English is not simply done in the classroom and what students need to facilitate their language improvement is, among others, doing autonomous learning. Foreign language learners face more serious problems of independent learning. Thus, they need some strategies enabling them to get the success. Those learners realize that what they get in a formal study does not seem to support all the learning experiences; thus, they liked to undertake a formal study as well as doing some autonomous activities of their own choice. In this case, students in learning a foreign language need to know what 
autonomous learning is. It seems very beneficial to describe the learning process called self-study concept that there is no direct teacher's intervention and learners are freely choose the material they want to learn and use, when they want to study, and how the learning process, and of course how it will be assessed, then the use of autonomous language learning (ALL) to the highest level.

By the development of this concept, it is about fostering the learners' autonomous character in learning becomes a pivotal concern. Successful language learners tend to be independent and autonomous in doing a self-study. They study by reading text books or English articles, listening to English songs, listening to news programs, watching talk show programs or western movies, and translating papers and song lyrics, and seeking an opportunity to practice independently (for example, by joining English conversation clubs, debate clubs, and interactive radio program in English; speaking and making contact with native speakers and English teachers; and being an English debate coach). The language learners mentioned above try to get language exposures from any sources. When someone is exposed to the language, he or she can get language input to be internalized.

Seen from other strong aspects, motivation and attitude have also been considered as strong factors influencing the success of learning a language, two different clusters of attitude are divided by Brown (2000) into basic types of motivation: integrative and instrumental. The integrative side describes learners who study a language since they wish to blend themselves into the culture of target language and being involved in a social interaction in that group. Instrumental side, on other hand, is having the language as tool to grab the objective of instrument: elevating career, helping to get idea of reading text, and so forth. Studies of motivation in language learning indicate that extrinsically motivated behaviors (instrumental motivation) are those actions carried out to achieve some instrumental purposes. Integrative motivation appears only when learners have a greater interest in the cultural and intellectual values related to the target language and new stimuli occur during the process of learning and using the particular language. 
Learners of a foreign language can be more successful if they feel that they need to learn the foreign language. It means that they are well-motivated. They can feel demotivated when they realize that their English will never reach the level of native of the language. Some learners do not feel easy with error correction. They dislike people correcting things that they have already known, but appreciate it at the time it is thing which is uncounted or illogic. They are pushing on themselves, indeed when they repeat mistakes that shows contrast to famous research suggesting that positive self-talk is used by a good language learner uses to combat anxiety (Tanveer, 2007). The nature makes speaker feel frustrated and anxious in certain times, the point is about how to cope them since they affect the motivation.

Learners should understand that the possibility to be perfect in the whole time using the language is too little and the existence of error is inevitable. Then, this unlucky situation may boost their spirit, as it looks to encourage them to learn more. They have the urgency to learn the language, such as preparing for their job, and connecting people around, to take all possible way to practice.

According the previous discussion, we can see that they are learners with high aspirations and a strong need for achievement. They also display most of the motivational characteristics that Tanveer (2007) considered to be significance of learning language. This includes willingness to speak, being emphatic with English culture and foreigners, and being tolerant and open-minded attitude towards the foreign language. They do not, however, apply positive self-talk to avoid anxiety.

When we take a look at another point about what the learners do improving their language, we can also see that learners do copy the language accents in English. Since learning is different with acquisition, it is critical where big portion of people have skills to mimic foreign sounds, otherwise only some of them that having low inhibition would actually achieve results.

Most of learners above are realized about their leading sensory style that is working with picture or visual aid, in general learning, but both auditory and visual styles are when they learn a 
language. They in certain times need to look at word that is written down before they can memorize it. They most of the time memorize by imaging and have obstacles memorizing verbal instructions.

Seen from the personality behavior, they are extrovert and having excellent self-confident; they also said that they learnt language easily. They are assertive learners in big portion of time, and possible to be careless or careful, it depends on the situations. They can be described as interested, strong-willed, opinionated, intellectual, passionate, creative, energized, and stubborn. They are easy going and active in speaking, amused by abroad cultures and brave to make mistakes in using a foreign language as learning foreign language experience.

Seen from their language grade and language achievements, those language learners above can be categorized as intelligent people. As being recommended before, their high intelligent may be influenced if only by their persistence. This skill seems to help them in continuous development of their language abilities.

Since language uses are various, and because each particular strategy may be useful for maintaining several different language users, it is hard to indicate the best one the learners can use. Only the individual learner can decide this. Learners will know whether a particular strategy is appropriate for them or not but they may often have to learn specific strategies in the first place.

\subsection{Dominant Language Learning Strategies}

By result of administering questionnaire to the learners, the researcher has found that the most dominant strategy used by the high achievers is compensation as shown in table 6 .

Table 6. Dominant Language Learning Strategies Used by each Learner

\begin{tabular}{lccc}
\hline $\begin{array}{c}\text { language learning } \\
\text { strategies }\end{array}$ & Freq & Calculation & Percent \\
\hline $\begin{array}{l}\text { Direct } \\
\text { Memory }\end{array}$ & 2 & $2 / 10 \times 100 \%$ & $20 \%$ \\
\hline
\end{tabular}


Muslimin, A. I., Dominant Language ...

\begin{tabular}{lccc}
\hline Cognitive & 1 & $1 / 10 \times 100 \%$ & $10 \%$ \\
Compensation & 3 & $3 / 10 \times 100 \%$ & $30 \%$ \\
$\begin{array}{l}\text { Indirect } \\
\text { Metacognitive }\end{array}$ & 2 & $2 / 10 \times 100 \%$ & $20 \%$ \\
Affective & 1 & $1 / 10 \times 100 \%$ & $10 \%$ \\
Social Strategies & 1 & $1 / 10 \times 100 \%$ & $10 \%$ \\
\hline Total & 10 & $10 / 10 \times$ & $100 \%$ \\
& & $100 \%$ & \\
\hline
\end{tabular}

Compensation strategy is one of direct strategy that enable the learner to guess the difficult word meaning through any clues like context, words formation, sounds, or anything that made them possible to grab the meaning. In short, mostly the successful MDDSs in English class are good guessers. They guessed the unfamiliar or difficult words was for overcoming their limitation in English not only in speaking and writing but in all four skills. The second favorite strategy applied by the students in learning English are memory and metacognitive. The learners used direct strategy to keep English words and expression by memorizing them in their mind. Sometimes, they created image or acted the words in order to retain their memory. After they had memorized their vocabulary, they reviewed their understanding through relearning the materials or making notes. So, in short they used both physical and mental process in understanding and learning English.

Another second favorite strategy which was used by the high achievers was indirect strategy that is metacognitive strategy. Here, the learners practice English through finding the best setting to learn, such as finding partners to learn, attending class, and reviewing the progress of learning.

According to previous discussion, the successful MDDSs used all language learning strategy. Only MAA(see Appendix 1) that did not use social strategy though he used all other strategies. It means that successful non-English department students believe that exactly all language strategies are good for their language learning improvement. Furthermore, there were dominant language 
learning strategies which are more often used by the students, they are: compensation, memory, and metacognitive strategies. Those were used by more than one student to improve their English score. The most frequently used one was compensation strategy which was used by all successful Non-English Department Students. It is because compensation strategy is one of direct strategy that enable the learner to guess the difficult word meaning through any clues like context, words formation, sounds, or anything that made them possible to grab the meaning. In simple way, mostly the successful MDDSs in English class are good guessers. They guessed the unfamiliar or difficult words was for overcoming their limitation in English not only in speaking and writing but in all four skills

The second most often used language learning strategies were memory and metacognitive. The learners used direct strategy to keep English words and expression by memorizing them in their mind which shows that they frequently used memory strategy. Sometimes, they created image or acted the words in order to retain their memory. After they had memorized their vocabulary, they reviewed their understanding through relearning the materials or making notes. So, in short they used both physical and mental process in understanding and learning English.

The similar average score for SILL questionnaire as memory strategy was indirect strategy that was metacognitive strategy. Here, the learners practice English through finding the best setting to learn, such as finding partners to learn, attending English class, and reviewing the progress of learning.

\section{CONCLUSION AND IMPLICATION}

The conclusions that can be grabbed from the study are: First, Non-English department students used all language learning strategies and creating their own learning opportunities. Only did HN (see Appendix 1) not use social strategy though he used all other strategies. It means that successful non-English department students believe that exactly all language strategies are good for their language learning improvement. From the questionnaire, we 
learn that what they do outside the classroom has a greater portion in improving their language competence. It is important to note that they actively involve themselves in classrooms activities and some other activities outside the classroom which are related to their interest and hobbies. Their reason is basically that they love and enjoy doing such activities. In short, the English language learners do a lot of independent learning activities which suit their interest. They used direct and indirect learning strategies though they seemed not really realizing in suing the strategies before. However, they believed that those strategies are helpful for boosting and maintaining their language.

Second, dominant language learning strategies are compensation as they are good guesser for the unfamiliar words, memory strategy since they always try to memorize to retain the vocabulary in mind, and metacognitive strategy where they always create best setting for them to learn.

\section{REFERENCE}

Ahmed, M. K. (2014). The ESP teacher: Issues, tasks, and challenges. English for Specific Purposes World, 15, 1-33.

Brown, H. D. (2000). Principles and practices of language learning and teaching (4th ed.). New York: Addison Wesley Longman.

Creswell, J. W. (2012). Qualitative inquiry and research design: Choosing among five approaches. Thusand Oaks, CA: Sage.

Day, J., \& Krzanowski, M. (2011). Teaching english for specific purposes: An introduction. London: Cambridge University Press.

Dornyei, Z., \& Ryan, S. (2015). The psychology of language learner: Individual difference in SLA (Rev. Ed.). New York: Routledge.

Mistar, J. (2009). Learning strategies by Indonesian senior high school EFL learners. Korea TESOL Journal, 10, 52-68.

Oxford, R. L., \& Crookall, D. (1989). Research on language learning strategies: Methods, findings, and instructional issues. Modern Language Journal, 73, 404-19.

Oxford, R. L. (1990). Language learning strategies: What every teacher should know. New York: Newbury House. 
Oxford, R. L. (2003). Language learning styles and strategies: An overview learning styles and strategies. Proceedings of GALA (Generative Approaches to Language Acquisition) Conference, 1-25. Retrieved from

http://web.ntpu.edu.tw/ language/workshop/read2.pdf

Peacock, M., \& Ho, B. (2003). Students language learning strategies across eight disciplines. International Journal of Applied Linguistics.13, 179-200.

Rachmawati, Y. (2013). Language Learning Strategies Used by Learners in Learning Speaking. Journal of English and Education, (1), 124-131.

Saville-Troike, M. (2006). Introducing second language acquisition. Cambridge: Cambridge University Press.

Sulistyo, G. H. (2008). Pengembangan tes kemampuan memahami teks akademik berbahasa inggris (Doctoral dissertation).Universitas Negeri Jakarta, Jakarta.

Tam, K. C. H. (2013). A Study on language learning strategies (LLSs) of university students in Hong Kong. Taiwan Journal of Linguistics, 11.2, 1-42. doi: 10.6519/TJL.2013.11(2).1.

Tanveer, M. ((2007). Investigation of the factors that cause language anxiety for ESL/EFL learners in learning speaking skills and influence it casts on communication in the target language (Master's Thesis). Retrieved from https://www.researchgate.net/publication/293263722 
INVESTIGATING THE EFFECT OF SELF-REGULATED STRATEGY DEVELOPMENT ON TERTIARY EFL STUDENTS' WRITING SKILLS

\author{
Kasyfur Rahman ${ }^{a}$, \\ a UIN Mataram, kasyfurrahman@uinmataram.ac.id \\ Imansyah $b$ \\ b IKIP Mataram, imansyah022@gmail.com \\ I Made Permadi Utamac \\ c IKIP Mataram, permadi_utama@yahoo.co.id
}

\begin{abstract}
This study aimed to investigate the relative effect of Self-Regulated Strategy Development (SRSD) teaching approach on tertiary EFL students' writing. During two months, sixty EFL University students enrolling in basic writing course took part in this project and were divided into experimental and control groups. Pre- and post-tests were carried out to garner the intended data pertinent to the students' writing scores. A mixed-design ANOVA was carried out to analyze the changes of writing scores of the respective groups since the assumption of homogeneity of regression slopes for the planned Analysis of Covariance was not met. The statistical evidence showed that there was a significant difference between the two groups in terms of writing scores at the significant value sig $.00<.05$. The data also suggested that students who were taught using SRSD relatively outperformed their counterparts in the control group. The empirical evidence demonstrates that the use of SRSD as an instructional approach to some extent positively affects EFL students' writing skill.
\end{abstract}

Keywords: Self-Regulation Strategy Development, writing strategy, writing skill

\title{
.INTRODUCTION
}

Writing is an intricate process taking into account such cognitive processes as choosing lexical items, binding words together and a constant checking of the piece of writing. These highly complex processes may lead to the term cognitive overload 